\title{
Assessment of Water Handling and Sanitation Practices Among Rural Communities of Farta Woreda, Northwest Ethiopia
}

\author{
Genet Gedamu Kassie*, Desta Haftu Hayelom \\ Department of Public Health, College of Medicine and Health Sciences, Arba Minch University, Arba Minch, Ethiopia
}

Email address:

geni_31280@yahoo.com (G. G. Kassie)

${ }^{*}$ Corresponding author

To cite this article:

Genet Gedamu Kassie, Desta Haftu Hayelom. Assessment of Water Handling and Sanitation Practices Among Rural Communities of Farta Woreda, Northwest Ethiopia. American Journal of Health Research. Vol. 5, No. 5, 2017, pp. 119-124. doi: 10.11648/j.ajhr.20170505.11

Received: June 12, 2017; Accepted: June 20, 2017; Published: August 11, 2017

\begin{abstract}
Worldwide, 663 million people do not have access to improved drinking water supplies and 2.5 billion people lack access to improved sanitation including one billion who practice open defecation. Eighty-eight percent of deaths from diarrheal diseases are attributable to unsafe water, inadequate sanitation, and insufficient hygiene practices. So this study is aimed at assessing water handling and sanitation practice among rural communities of Farta woreda, North West Ethiopia. A community based cross-sectional study was conducted in Farta Woreda in March 2014. A total of 834 households were proportionally allocated to 10 kebeles of the Woreda and selected by systematic random sampling technique. Data was collected using a pretested structured questionnaire. Descriptive analysis was performed to obtain the frequency distribution of the variables. The majority of respondents used unprotected spring 313 (37.5\%) followed by protected spring 206 (24.7\%) for all domestic use. Most respondents $382(92.5 \%)$ had covered their stored water and practiced pouring method to withdraw water from the stored container. Majority 738 (88.5\%) of households had access to water within a time of 30 minutes or less. House hold water treatment was not common in the study area, only $23(2.8 \%)$ households practiced. About four hundred seventy eight $(57.3 \%)$ households had latrine facility, of which $263(55 \%)$ was open pit latrine. Of those households having latrine only 102 $(21.3 \%)$ households had hand washing facility. This study revealed that most of the respondents had poor water handling and sanitation practice. Thus, it underscores that there should be great attention.
\end{abstract}

Keywords: Water Handling, Sanitation, Ethiopia, Rural Community

\section{Introduction}

Access to safe water alone does not reduce diarrheal diseases significantly. Even if the source is safe, water become faecally contaminated during collection, transportation, storage and drawing in the home. Water and sanitation are among the most important determinants of public health and an adequate supply of clean water is one of the most basic human needs and one that must be met [1].

Sanitation practices have a major effect on community and household water issues. In most rural communities, the use of on-site sanitation is a common tradition, which is not hygienic for health. As a result of this, there is a growing concern that the wide spread use of on-site sanitation systems will cause sub-surface migration of contaminants, ultimately resulting in disease transmission and environmental degradation. Surface waters such as rivers and ponds undergo such degradation as they are subject to biological and chemical contamination [2].

About 2.4 billion people lack access to improved sanitation including one billion who practice open defecation. Moreover, nearly 1 in 4 people in developing countries were practicing open defecation [3]. Approximately eighty-eight per cent of cases of diarrhea worldwide are attributable to unsafe water, inadequate sanitation or insufficient hygiene. The proportion of population in rural areas with access to safe drinking water and sanitary latrines has a direct impact on the health of the masses [4].

Water sources and improper water handling practices constitute the socio risk factors of waterborne infectious 
diseases. In addition to water sources, water collection, water storage in appropriate vessel and point-of-use treatment have been shown to greatly reduce diarrhoea generally and cholera specifically $[5,6]$.

Ethiopia has the lowest water supply and sanitation coverage. According to data from WHO and UNICEF estimated in 2008 only $38 \%$ of total population had access for improved water supply (98\% for urban areas and $26 \%$ for rural areas), $12 \%$ had access for improved sanitation (29\% in urban areas, $8 \%$ in rural areas) [7].

People living in rural communities are the population sector most affected by hydro-transmissible infectious pathogen agents. Therefore, controlling of water quality is one of the essential issues of drinking water management [8, 9]. There for the objective of this study was to assess water handling and sanitation practice among rural community.

\section{Methods and Materials}

\subsection{Study Area}

The study was conducted in Farta Woreda which is one of the 12 Woredas found in South Gonder zone, Amhara regional state of Ethiopia. The Woreda consists of 2 urban kebeles and 41 peasant associations (PAs). According to 2007 national housing and population census the projected estimated population of the Woreda for the year 2013/14 was 281,279 . Agriculture is the main livelihood of the population, with potato, barley, teff, wheat, maiz, guya, bean, are the main crops cultivated in the Woreda. There are 10 health centers and 54 health posts providing health service for the Woreda population. According to 2013/14 report of Farta Woreda health office, the woreda had $88.4 \%$ \& $85.2 \%$ health service and latrine utilization coverage respectively. The same year report of Farta Woreda water resource office showed that the Woreda had 1020 functional improved drinking water sources which includes 203 protected springs, 791 protected hand pumps dug well and 26 hand dug well. All these contribute $75.7 \%$ of improved water supply access in the Woreda.

\subsection{Study Design}

A community based cross- sectional study was conducted using interviewer-administered questionnaire in March 2014.

\subsection{Source Population}

All households found in 41 rural kebeles of Farta Woreda

\subsection{Study Population}

Selected households found in 10 rural kebeles of Farta Woreda

\subsection{Inclusion and Exclusion Criteria}

Respondents lived at least for 6 month in the study area were included and respondents who were critically ill and other mental problems that prevents to get the required information were excluded from the study

\subsection{Study Variables}

Household water handling and Sanitation practice, age, education, occupation and marital status of the respondent, family size, type, ownership and availability of latrine, hand washing facility of latrine, water source, distance from house to water source, daily water consumption, ways of refuse disposal, types of floor and roof construction material and number of rooms, Latrine utilization, hand washing practice were variables included in the study.

\subsection{Sample Size Determination}

The total sample size included in the study was calculated by using Epi Info window version 3.5.3 statistical software manufactured by Centers for Disease Control and Prevention (CDC) in Atlanta, Georgia (USA). A single population proportion formula used by considering 95\% confidence level, Proportion of households covered their storage container from previous study was 52\% (0.52), margin of error $5 \%$, design effect of 2 and $10 \%$ non response rate give the total sample of 834 HHs.

\subsection{Sampling Procedures}

Multi-stage sampling technique was used. Ten rural kebeles were selected randomly by lottery method from 41 rural kebeles of the Woreda and included in the study. After allocating the sample in to each kebele proportionally 834 households were selected by using systematic random sampling technique (every other household).

\subsection{Data Collection Tools and Procedures}

Data was collected using pretested structured questionnaire and observational check list. The questionnaire had three parts that was designed to cover socio-economic and demographic status, home and environmental health conditions and behavioral aspects of respondents. The questions were developed after reviewing of relevant literature and in addition to literature questions regarding to environmental factors were adapted from WHO core questions for drinking water and sanitation facilities. Respondents for the administered questionnaire were females that had lived in the household for the preceding six months. Ten data collectors, who completed 12th grades and two diploma environmental health professionals as supervisors were recruited for the whole data collection process. The interviewers physically observed the condition of house hold water handling practices and utilization of sanitation facilities. The supervisors were fully responsible to lead and handle the whole session of data collection process along with the principal investigator.

\subsection{Data Quality Management and Analysis}

Two days training of data collectors and supervisors on sampling procedures, techniques of interviews and data 
collection process was performed. In addition the data collectors and supervisors were participated in pre-testing of the questionnaire for its understandability by $5 \%$ of sample size in another kebele with the same level in every aspects of basic infrastructure and socio-demographic characteristics in the study area which were not included in the study and the result of the pretest was used to correct some unclear ideas and statements. During data collection the supervisors and principal investigator had closely followed the day-to-day data collection process and ensure completeness and consistency of questionnaire administered each day. After data collection the collected information was rechecked for its completeness and consistency by the supervisors and principal investigators before transferring in to computer software. Non over lapping numerical code was given for each question and the coded data was entered and cleaned into Epi Info soft ware Version 3.5 .3 by doing simple frequency and cross tabulation and transformed to SPSS version 20. Descriptive statistic including proportion, mean and standard deviations were performed to describe the sample population in relation to relevant variables.

\subsection{Operational Definitions}

Improved water sources: includes Piped water into dwelling, Piped water to yard/plot, Tube well or borehole, Public standpipes, protected dug wells, protected springs and Rainwater. "Improved" source is one that is likely to provide "safe" water [10].

Improved sanitation facilities: includes flush toilet, piped sewer system, septic tank, ventilated improved pit latrine (VIP), pit latrine with slab, composting toilet [10].

Proper hand washing facility: household having functional hand washing facility with water in the container and moisture under the container.

High contamination risk in household water handling practices: is the sanitary risk score of 8-10 from the total 12 questions which is used to measure household water handling practice [11]

Medium contamination risk in household water handling practices: is the sanitary risk score of 5-7 from the total 12 questions which is used to measure household water handling practice [11]

Low contamination risk in household water handling practices: is the sanitary risk score of 2-4 from the total 12 questions which is used to measure household water handling practice [11]

Proper latrine utilization: households with functional latrines and at least no observable faeces in the compound, observable fresh faeces through the squat hole and the footpath to the latrine were uncovered with grasses.

Good hand washing practice: hand washing practices at least three times out of five critical times of hand washing practice.

Proper refuse disposals a way of disposal which included, burning, burying in a pit or storing in a container and disposing in designed site.

\section{Results and Discussion}

\subsection{Socio-demographic and Economic Characteristics of the Respondents}

The majority $793(95.1 \%)$ of the respondents were females, Married 781 (93.6\%), Illiterate 547 (65.6), Orthodox in religion (99.8\%) and Amhara (100\%) in ethnicity. The mean $( \pm \mathrm{SD})$ ages of the respondents were $31( \pm 7)$ years. Seven hundred twenty six $(87.1 \%)$ respondents were farmers. The mean household family size of the study population was $5( \pm 2)$ persons. Five hundred eight $(60.1 \%)$ households had five or more persons in their families (Table 1).

Table 1. Socio demographic characteristics of the respondents in Farta Woreda, Northwest Ethiopia, March, $2014(n=834)$.

\begin{tabular}{|c|c|c|}
\hline Characteristics & Frequency & Percent \\
\hline \multicolumn{3}{|l|}{ Sex } \\
\hline Female & 793 & 95.1 \\
\hline Male & 41 & 4.9 \\
\hline \multicolumn{3}{|l|}{ Age of respondents } \\
\hline $15-24$ & 141 & 16.9 \\
\hline $25-34$ & 428 & 51.3 \\
\hline$>34$ & 265 & 31.8 \\
\hline \multicolumn{3}{|l|}{ Marital status of respondent } \\
\hline Married & 781 & 93.6 \\
\hline Divorced & 28 & 3.4 \\
\hline Others $^{\mathrm{a}}$ & 25 & 2.9 \\
\hline \multicolumn{3}{|l|}{ Educational level of respondent } \\
\hline Illiterate & 547 & 65.6 \\
\hline Can read and write & 144 & 17.3 \\
\hline Primary school & 105 & 12.6 \\
\hline Secondary school and above & 38 & 4.6 \\
\hline \multicolumn{3}{|l|}{ Occupation of respondent } \\
\hline Farmer & 726 & 87.1 \\
\hline Government employee & 6 & 0.7 \\
\hline Merchant & 14 & 1.7 \\
\hline Daily laborer & 88 & 10.6 \\
\hline \multicolumn{3}{|l|}{ Religion } \\
\hline Orthodox & 832 & 99.8 \\
\hline Muslim & 2 & 0.2 \\
\hline \multicolumn{3}{|l|}{ Family size } \\
\hline$\leq 4$ & 326 & 39.1 \\
\hline$\geq 5$ & 508 & 60.9 \\
\hline
\end{tabular}

$\mathrm{a}=$ single and widowed

\subsection{Water Source and Household Water Handling Practice}

The major source of water supply for the study household were Unprotected spring 313 (37.5\%) followed by protected spring 206 (24.7\%) and contributes 449 (53.8\%) improved water supply access of study households. This is consistent with a study conducted in rural Dire Dawa communities, Ethiopia [12]. The majority of households 738 (88.5\%) required less than 30 minutes to fetch drinking water and the mean per capita daily water consumption of the households was $10.2( \pm 4.4)$ liters. Of the total 834 households, 121 $(14.5 \%), 146(17.5 \%)$ and $567(68 \%)$ households were at high, medium and low contamination risk in household water handling practices respectively. 


\subsection{Water Handling Practice Related to Water Collection}

Adult women $639(76.6 \%)$ followed by 160 (19.2\%) female child (under 15 years) were responsible for the collection of water for domestic use. The study revealed that the most $789(94.6 \%)$ commonly preferred type of water collection container was Jerrican. This finding is in agreement with similar study done in Dire Dawa rural communities and Kolladiba Town [13, 12]. From the total respondents, the majority $579(64.4 \%)$ and $743(89.1 \%)$ were clean their container and wash their hands before collection of water respectively. In addition, majority 793 (95.1\%) of the respondents were cover the collection container during transportation.

Table 2. Water source and water collection practice among households in rural kebeles of Farta Woreda, Northwest Ethiopia, March, 2014.

\begin{tabular}{lll}
\hline Characteristics & Frequency & Percent \\
\hline Source of drinking water & & \\
Public tap/stand pipe & 68 & 8.2 \\
Protected hand dug well & 172 & 20.6 \\
protected spring & 206 & 24.7 \\
Unprotected dug well & 58 & 7.0 \\
Unprotected spring & 313 & 37.5 \\
surface water (river, lake, dam) & 17 & 2.0 \\
Time taken to obtain drinking water (round trip) & & \\
<30min & 738 & 88.5 \\
>=30min & 96 & 11.5 \\
Person who collect drinking water & & \\
Adult woman & 639 & 76.6 \\
Adult man & 16 & 1.9 \\
Female child (under 15 years) & 160 & 19.2 \\
Male child (under 15 years) & 19 & 2.3 \\
Water collection container & & \\
Clay Pot & 29 & 3.5 \\
Plastic bucket & 7 & 0.8 \\
Iron bucket & 9 & 1.1 \\
Jerrycan & 789 & 94.6 \\
Hand washing before water collection & & \\
Yes & 579 & 69.4 \\
No & 255 & 30.6 \\
Collection container rinsing or washing & & \\
Yes & 743 & 89.1 \\
No & 91 & 10.9 \\
Covering of water collection container & & \\
Yes & 793 & 95.1 \\
No & 41 & 4.9 \\
\hline
\end{tabular}

\subsection{Water Handling Practice Related to Household Water Storage}

Four hundred ninety five (59.4\%) of the households used Jerrican followed by clay pot $180(21.6 \%)$ to store water at household and About 338 (40.5\%) of the respondents used separate containers to store water for drinking purposes. This is used in many African countries storing water using Jerrican [14]. Similarly majority 753 (90.3\%) of the households covered the storage containers during data collection time but the sanitation near to the storage containers was poor and only $148(17.7 \%)$ drinking water storage containers kept as WHO recommendation $(40 \mathrm{~cm}$ above the floor ) [11]. Pouring method for drawing water from storage containers was used commonly by 609 (73\%) of the respondents and separate cane for taking drinking water from the storage container used by $331(39.7 \%)$ respondents. After use, drinking utensils were mostly kept on table by 399 (47.8\%) followed by floor $290(34.8 \%)$ respondents. This finding is in line with a study done in Bahirdar city and Adama town $[15,16]$.

Eight hundred twenty one $(98.4 \%)$ respondents wash water storage container before storing water, of which 528 (63.3\%) washed every day followed by $251(30.1 \%)$ every other day and the majority $554(66.4 \%)$ of households stored water for one day. Treating water was not common in the study area, only $23(2.8 \%)$ households practiced water treatment method of which around 12 households used leach/chlorine to treat drinking water (Table 3). This is finding is similar with a study done in Sidama zone, southern Ethiopia [17].

Table 3. Household water storage practice among households in rural kebeles of Farta Woreda, Northwest Ethiopia, March, 2014.

\begin{tabular}{|c|c|c|}
\hline Characteristics & Frequency & Percent \\
\hline \multicolumn{3}{|l|}{ Water storage container } \\
\hline Clay Pot & 180 & 21.6 \\
\hline Plastic bucket & 152 & 18.2 \\
\hline Iron bucket & 7 & .8 \\
\hline Jerrycan & 495 & 59.4 \\
\hline \multicolumn{3}{|l|}{ Separated drinking water storage container } \\
\hline Yes & 338 & 40.5 \\
\hline No & 496 & 59.5 \\
\hline \multicolumn{3}{|l|}{ Drinking water kept above floor level $(40 \mathrm{~cm})$} \\
\hline Yes & 148 & 17.7 \\
\hline No & 686 & 82.3 \\
\hline \multicolumn{3}{|l|}{$\begin{array}{l}\text { Drinking water storage containers have a } \\
\text { narrow mouth }\end{array}$} \\
\hline Yes & 610 & 73.1 \\
\hline No & 224 & 26.9 \\
\hline \multicolumn{3}{|l|}{ Drinking water storage containers have a cover } \\
\hline Yes & 753 & 90.3 \\
\hline No & 81 & 9.7 \\
\hline Water drawing technique from storage container & 609 & 73.0 \\
\hline Pouring & 225 & 27.0 \\
\hline \multicolumn{3}{|l|}{ Dipping } \\
\hline \multicolumn{3}{|l|}{$\begin{array}{l}\text { Separate cane for taking drinking water from } \\
\text { the storage container }\end{array}$} \\
\hline Yes & 331 & 39.7 \\
\hline No & 503 & 60.3 \\
\hline \multicolumn{3}{|l|}{ Placement of drinking utensils } \\
\hline Table or shelves & 399 & 47.8 \\
\hline Inside the container & 26 & 3.1 \\
\hline Storage cover & 119 & 14.3 \\
\hline Floor & 290 & 34.8 \\
\hline \multicolumn{3}{|l|}{$\begin{array}{l}\text { Wash water storage container before storing } \\
\text { water }\end{array}$} \\
\hline Yes & 821 & 98.4 \\
\hline No & 13 & 1.6 \\
\hline \multicolumn{3}{|l|}{ Frequency of washing } \\
\hline Every day & 528 & 63.3 \\
\hline Every other day & 251 & 30.1 \\
\hline Every week & 51 & 6.1 \\
\hline Every month & 4 & 0.4 \\
\hline \multicolumn{3}{|l|}{ Duration of water stored in the container } \\
\hline less than one day & 88 & 10.6 \\
\hline one day & 554 & 66.4 \\
\hline greater than day & 192 & 23.0 \\
\hline \multicolumn{3}{|l|}{ Treat water to make it safer to drink } \\
\hline Yes & 23 & 2.8 \\
\hline No & 811 & 97.2 \\
\hline
\end{tabular}




\begin{tabular}{lll}
\hline Characteristics & Frequency & Percent \\
\hline Treatment methods & & \\
Boiling & 6 & 0.7 \\
Add leach/chlorine & 12 & 1.4 \\
Strain it through a cloth & 2 & 0.2 \\
Let it stand and settle & 3 & 0.4 \\
\hline
\end{tabular}

\subsection{Housing Condition and Sanitation Practice}

From the total households, $828(99.3 \%), 629$ (75.4\%) and $816(97.8 \%)$ had dwelling with mud floor, corrugated roof, Timber and mud wall respectively. Three hundred sixty $(43.2 \%)$ dwelling houses had three and more living rooms and $403(48.3 \%)$ households shared their living rooms with animals.

About four hundred seventy eight (57.3\%) households had latrine facility, of which $263(55 \%)$ was open pit followed by $204(42.7 \%)$ pit latrine without slab and 445 (93.1\%) had privately owned. The extent of the latrine utilization habit of households in the study area was improper, only 134 (28.1\%) of the households used latrine properly. Of the households having latrine $259(72.9 \%)$ used latrine for disposal of child feces.

In addition of those households having latrine, only 102 $(21.3 \%)$ of households had hand washing facility, of which water and soap were available only in 41 and 10 households respectively. Regarding to hand washing practice habit at five critical times, $347(41.6 \%)$ were claimed to poor hand washing practice. From those practicing hand washing, above half of $492(59 \%)$ the respondent used only water to wash their hands. Open field 323 (38.7) followed by private pit 144 (17.3) were the common methods for the disposal of solid waste in the study area.

Table 4. Housing condition and Sanitation practice among households in rural kebeles of Farta Woreda, March, 2014.

\begin{tabular}{|c|c|c|}
\hline Characteristics & Frequency & Percent \\
\hline \multicolumn{3}{|l|}{ Types of floor material } \\
\hline Mud & 828 & 99.3 \\
\hline Others $^{\mathrm{b}}$ & 6 & 0.7 \\
\hline \multicolumn{3}{|l|}{ Types of Roof material } \\
\hline Thatched & 205 & 24.6 \\
\hline Corrugated iron sheet & 629 & 75.4 \\
\hline \multicolumn{3}{|l|}{ Types of Wall material } \\
\hline Timber and mud & 816 & 97.8 \\
\hline Others $^{c}$ & 18 & 2.1 \\
\hline \multicolumn{3}{|c|}{ Number of living rooms for humans } \\
\hline 1 & 177 & 21.2 \\
\hline 2 & 297 & 35.6 \\
\hline$>=3$ & 360 & 43.2 \\
\hline \multicolumn{3}{|l|}{ Separate kitchen } \\
\hline Yes & 594 & 71.2 \\
\hline No & 240 & 28.8 \\
\hline \multicolumn{3}{|l|}{ Animal live with human } \\
\hline Yes & 403 & 48.3 \\
\hline No & 431 & 51.7 \\
\hline \multicolumn{3}{|l|}{ Latrine facility available } \\
\hline Yes & 478 & 57.3 \\
\hline No & 356 & 42.7 \\
\hline \multicolumn{3}{|l|}{ Type of latrine $(\mathrm{n}=478)$} \\
\hline Pit latrine with slab & 11 & 2.3 \\
\hline
\end{tabular}

\begin{tabular}{|c|c|c|}
\hline Characteristics & Frequency & Percent \\
\hline Pit latrine without slab & 204 & 42.7 \\
\hline open pit & 263 & 55 \\
\hline \multicolumn{3}{|c|}{ Ownership of latrine $(\mathrm{n}=478)$} \\
\hline Private & 445 & 93.1 \\
\hline Shared & 33 & 6.9 \\
\hline \multicolumn{3}{|c|}{ Latrine utilization $(\mathrm{n}=478)$} \\
\hline Proper & 134 & 28.1 \\
\hline Improper & 344 & 71.9 \\
\hline \multicolumn{3}{|c|}{$\begin{array}{l}\text { Disposal system of feces of children } \\
(\mathrm{n}=355)\end{array}$} \\
\hline Proper & 259 & 72.9 \\
\hline Improper & 96 & 27.1 \\
\hline \multicolumn{3}{|c|}{ Hand washing facility $(\mathrm{n}=478)$} \\
\hline Yes & 102 & 21.3 \\
\hline No & 376 & 78.7 \\
\hline \multicolumn{3}{|c|}{ Soap near to hand washing facility $(\mathrm{n}=102)$} \\
\hline Yes & 10 & 9.8 \\
\hline No & 92 & 90.2 \\
\hline \multicolumn{3}{|c|}{$\begin{array}{l}\text { Water inside the hand washing facility } \\
(\mathrm{n}=102)\end{array}$} \\
\hline Yes & 41 & 40.2 \\
\hline No & 61 & 59.8 \\
\hline \multicolumn{3}{|l|}{ Hand washing practice } \\
\hline Good & 347 & 41.6 \\
\hline Poor & 487 & 58.4 \\
\hline \multicolumn{3}{|l|}{ Hand washing materials } \\
\hline Only water & 492 & 59.0 \\
\hline Soap \& water & 307 & 36.8 \\
\hline Ash \& water & 35 & 4.2 \\
\hline \multicolumn{3}{|c|}{ Method of Refuse disposal } \\
\hline Private Pit & 144 & 17.3 \\
\hline Communal Pit & 12 & 1.4 \\
\hline Composting & 131 & 15.7 \\
\hline Burring & 53 & 6.4 \\
\hline Burning & 171 & 20.5 \\
\hline Open Field & 323 & 38.7 \\
\hline
\end{tabular}

$\mathrm{b}=$ Cement, Wood: $\mathrm{c}=$ Timber and bamboo, Stone

\section{Conclusion}

The present study revealed that the water handling practice of the community was very poor, which showed that supply of safe water alone cannot guarantee that the water in the household for drinking purpose is safe as well. Sanitation practice in rural household is still very far from the recommended level. So efforts will be required to increase awareness regarding the components of household water handling and sanitation practice.

\section{References}

[1] Khan, A. H., The sanitation gap: Development's deadly menace. The progress of nations, 1997: p. 5-13.

[2] Odai, S. and Dugbantey, D. Towards pollution reduction in peri-urban water supply: A case study of Ashanti region in Ghana. in Diffuse Pollution Conference, Dublin. 2003.

[3] WHO. Progress on sanitation and drinking water - 2015 update and MDG assessment., 2015. 
[4] Prüss-Üstün, A., et al., Safer water, better health: costs, benefits and sustainability of interventions to protect and promote health. 2008: World Health Organization.

[5] Clasen, T. F. and Cairncross, S. Household water management: refining the dominant paradigm. Tropical Medicine \& International Health, 2004.9 (2): p. 187-191.

[6] Clasen, T. F. and Mintz, E. D. International network to promote household water treatment and safe storage. Emerging infectious diseases, 2004. 10 (6): p. 1179.

[7] WHO/UNICEF, Joint Monitoring Program for Water Supply and Sanitation: Ethiopia 2008 estimates, 2010.

[8] Sehar, S., et al., Monitoring of Physico-Chemical and Microbiological Analysis of Under Ground Water Samples of District Kallar Syedan, Rawalpindi-Pakistan. Research Journal of Chemical Sciences. ISSN, 2011. 2231: p. 606X.

[9] Udousoro, I. and Umor en, I. Assessment of Surface and Ground Water Quality of Uruan in Akwa Ibom State of Nigeria. Journal of Natural Sciences Research, 2014. 4 (6): p. 11-27.

[10] WHO and UNICEF. Core questions on drinking water and sanitation for household surveys. WHO Press Geneva, Switzerland. 2006: p. 6-20.

[11] Howard, G. Water quality surveillance A practical guide. 2002.
[12] Amenu, D., Menkir, S., and Gobena, T. Assessment of water handling practices among rural communities of Dire Dawa Administrative Council, Dire Dawa, Ethiopia. Science, Technology and Arts Research Journal, 2013. 2 (2): p. 75.

[13] Sharma, H. R., et al., Water Handling Practices and Level of Contamination Between Source and Point-of-Use in Kolladiba Town, Ethiopia Environ. We Int. J. Sci. Tech., 2013. 8: p. 2535 .

[14] CDC. The Safe Water System. 2010; Available from: https://www.cdc.gov/safewater/.

[15] Temsgen, E. and Hameed, S. Assessment of PhysicoChemical and Bacteriological quality of drinking water at sources and Household in Adama town, Oromiya Regional State, Ethiopia. African Journal of Environmental Science and Technology, 2015.9 (5): p. 413-.

[16] Milkiyas, T., Mulugeta, K and Bayeh, A. Bacteriological and Physico-Chmical Quality of Drinking water and hygienesanitation practices of the consumers in Bahirdar city, Ethiopia. Ethiop J Health Sci., 2011. 21 (1): p. 22-26.

[17] Abebe, B. and Dejene, H. Bacteriological and Physicochemical Quality of Drinking Water Sources and Household Water Handling Practice Among Rural Communities of Bona District, Sidama Zone-Zouthern, Ethiopia. Science Journal of Public Health, 2015. 3 (5): p. 782-789. 